\title{
A Comparative Analysis of Financing Performances of Listed Companies on GEM and the Influence Factors before and after IPO
}

\author{
Xiangdong Chen ${ }^{1}$, Fei Wang ${ }^{2 *}$ and Wei Wang ${ }^{3}$ \\ ${ }^{1}$ Professor, School of Economics and Management, Beihang University, XueYuan \\ Road No.37, HaiDian District, Beijing The People's Republic of China \\ ${ }^{2}$ Ph D, School of Economics and Management, Beihang University, XueYuan \\ Road No.37,HaiDian District, Beijing The People's Republic of China \\ ${ }^{3}$ M.Sc. Faculty of Geo-information Science and Earth Observation (ITC), \\ University of Twente, Hengelosestraat 99, 7514 AE Enschede, The Netherlands \\ 1'chenxdng@126.com 22warmfine@126.com \\ ${ }^{3}$ w.wang-1@student.utwente.nl
}

\begin{abstract}
Since the launch of Growth Enterprise Market (GEM) in China, its role in the capital market has become increasingly important. In recent years, many scholars have researched on the changing conditions of business performance before and after listing of Initial Public Offerings (IPO) companies. But most studies so far used directly selected traditional performances and innovative performance evaluation indexes to conduct a comparative analysis between conditions and innovations before and after IPO. Different from the previous studies, this paper cites the latest data of Chinese GEM at the end of 2014 in the selection of performance evaluation indexes and finds out the most influential ones on financing capacity based on correlation analysis; next, it further screens the indexes with regression tests; at last, it analyzes a comparative analysis of the screened indexes with the most significant influence on financing capacity before and after IPO. Thus the continuous changes of indexes with real influence on financing capacity before and after IPO can be revealed more objectively. Research findings suggest that enterprises' technological innovation input and numbers of annual patent applications increase continuously during the studied period and the research and development $(R \& D)$ intensity rises stably as well, indicating that as they develop continuously, enterprises have paid increasing attention on the enhancement of technological innovation capacity and the protection of patent and intellectual property. But each business performance indicator had obviously increased before the IPO and decreased after the IPO. This verifies that companies tried to "sugarcoat" their financial reports before the IPO which overrated the business performance. The companies were listed during the period of better business performance in order to achieve a higher issued premium price. After listing, performance may result in decrease of benefits.
\end{abstract}

Keywords: IPO; business performance; technological innovation

\section{Introduction}

In recent years, more scholars have begun to research on the financing significance of new high-tech enterprises on GEM and have analyzed the influencing factors of their financing capability. The changes of their business performance were also analyzed

\footnotetext{
* Corresponding author, Fei Wang, Ph D, School of Economics and Management,Beihang University, XueYuan Road No.37,HaiDian District,Beijing The People's Republic of China, warmfine@126.com
} 
before and after the IPO financing. Li Yanghui (2008) pointed out that the uniqueness of a high-tech company decides its use of GEM as new financing channel and withdrawal channel for venture investment [1]. Yiuman Tse,Erik Devos (2004) believed NASDAQ can provide financing platform for many high-tech enterprises and help them to attract more corporate investors, which brings plenty of earnings for these high-tech companies[2].

Moreover, China's GEM has also solved financing problems in small- and mediumscale companies on top of being an important tool in promoting and accelerating the development in the high-tech field. Enterprises achieve future development by seeking financing by listening on the stock market. Each company hopes to have better business performance during IPO and to attract more investors. Thus, more financing is achieved with a lower cost, which causes companies to try to "sugarcoat" their performance before the IPO and may see a decrease in performance after the IPO. This paper analyzed these two issues. The first one is to analyze factors that affected IPO financing capacity of these enterprises and to find performance indicators to measure these factors. The second issue is based on the first one. These selected performance indicators that affect financing capability as well as changes before and after IPO were analyzed.

\section{Theoretical Analysis and Research Hypothesis}

\subsection{Analysis of Financing Influences}

American scholar Ronald Gilson (1998) believed venture investment is the most important channel for the financing of high-tech industry in the US [3]. He pointed out that three factors, which are the capital, the financial intermediary and the company, should be considered based on the conditions of the country. Thus, a sturdy venture capital market was established and provided financial channels for the high-tech industry. Generally speaking, a company needs two external financing conditions. (1) The company has to face an attractive investment opportunity. (2) The internal cash flow of the company cannot meet the investment fund requirement. Tobin's Q represents the investment opportunity of the company which can reflect the investment value of the company at a certain level. Under the same conditions, a higher Q value means a higher investment value. The enterprise can gather more funding to invest. Therefore, the larger the $Q$ value, the more external financing the enterprise has. In international studies, Tobin s Q has already become a common proxy variable for the investment value of enterprises (Adam and Goyal, 2008)[4]. Although the development of stock market in China is not perfect and the market value estimates for Chinese listed companies are not very accurate, many scholars still use Tobin's $Q$ as the investment value, expected result of company development or measurement of company performance (Su, 2005[5]; Zhang and $\mathrm{Li}, 2005[6])$. However, there are many factors that affect the size of financing capability. Studies on this aspect are relatively mature. Wang Hecheng and Meng Yanfen (2004) argued in a enterprise competitive advantage perspective about the importance of financial capacity in the competence system [7]. Zheng Xiujie and Dong Liying (2006) believed financing capacity is an important part of the company's competence system and analyzed financing capacity of Chinese enterprises in different modes under different stages. Factors that affect financing capability included structure, volatility of earning, asset structure, profitability, scale of company and opportunity for company's growth [8]. Zhang Lihui and Yin Wen (2006) thought that financing capability is one of the important factors for the competitiveness of a listed company [9]. They applied factor analysis to study many factors that affected financing capability of listed electric companies. It was discovered that the main factors are capital structure, asset size, profitability, growth and company background. 
Based on that, this paper used Tobin's Q theory to represent the financial capability of an enterprise, combined with the $\mathrm{Y}$ value as a dependent variable to represent the financial value of an enterprise. It is represented as "the total value of equity capital in a listed company after financing with the specific value of the company's total asset" McLean and Zhao (2014)[10]. A company has tradable shares and non-tradable shares after the IPO, thus the total value of equity capital equals the values of tradable and nontradable shares. The value of non-tradable shares is the net asset value per share times the quantity of non-tradable shares.

At the same time, we selected 8 measurements, which are profitability, earnings quality, capital structure, growth ability, debt paying ability, operation capacity, shareholder structure and technological innovative ability, as well as 25 indicators to generally reflect the whole situation of business performance and innovative performance indicators that influence financing capability of a company before it is listed. These indicators were analyzed with the IPO financing capability of enterprises. This paper suggests hypothesis 1 :

Hypothesis 1: IPO financing capability of a company has a positive correlation with the company's business performance and innovative ability.

\subsection{Analysis of Changes in Business Performance before and after IPO}

For the research on the changes in performance before and after IPO, Chinese scholar Wen Bin (2001) sampled a company listed in the A share market in 1999[11]. The changes of business performance at the year of IPO and 3 years after IPO were analyzed and found that after IPO, the company's return on total assets had significantly dropped and showed a decline trend. Xie Lingfang and Zhu Xiaoming (2005) selected a private enterprise listed in the A share market from 1996 to 2001 as study sample and evaluated the changes in performance 2 years before and after listing [12]. The results were that the actual sales and financial condition of the enterprise had obviously improved after listing, only the rates of return were decreased. The decline of company performance after listing becomes a common phenomenon. Zhao Guoru (2009) sampled a private enterprise listed in the A share market between 2000 and 2002 then examined and verified its business performance 3 years before and after IPO[13]. The results showed that its business performance had a serious decline. Earlier on, Hansen and Crutchley (1990) used return on assets as a measuring indicator for company profit[14]. They studied the business performance of 109 listed companies with additional issues in stocks on NYSE in the US from 1975-1982. Research results indicated that company performance significantly decline after increase issues in stocks. Hei Wai Lee (1997) found that listed companies at a growing stage have declined performance after implementation of SEO while listed companies at a mature stage have increased performance [15]. Marc Goergen and Luc Renneboog (2003) chose companies listed in German and British markets between 1981 and 1988 as sample data [16]. Analysis showed that after the companies were listed, change in shareholder ownership had no significant declining effect on long-term business performance.

Before the IPO financing, company's performance and investment of technological innovative ability obviously increase while both of them significantly decrease after IPO. This phenomenon reflects the fluctuation in performance of listed companies before and after IPO. It also reflects how IPO affects the performance and innovation of a company. We carried out empirical survey on changes in performance of listed companies on GEM affected by financing before and after IPO in order to find out whether there is an IPO effect on the GEM in China. This paper suggests hypothesis 2:

Hypothesis 2: There is an IPO effect on GEM in China. 


\section{Data}

\subsection{Samples}

The GEM in China commenced operations in 2009. Until December 31, 2014, 414 companies complete successfully listed on the GEM. Due to the short development time of China' s GEM, there are three steps for selection of samples to remove the incomplete samples:

Firstly, 356 companies with complete financial data in financial reports 3 years before company listening and by 2014.12.31 after IPO.

Secondly, 16 companies with incomplete and abnormal data were removed.

Lastly, relevant research variables of all data are disclosed, true and complete in all sample companies.

This paper used 340 companies on GEM as study samples with public financial data and IPO data as basis. Otherwise, financial data of listed company came from the wind database. Patent data came from the website of State Intellectual Property Office.

\subsection{Variables}

\subsubsection{Explained Variable}

This paper used Tobin's Q theory to represent the financing capability of enterprises (Adam and Goyal, 2008)[4]. The formula is $Y_{1}$ (financing value of company) = total market value of company/total assets before IPO, and $\mathrm{Y}=$ (tradable share $\times$ share price + non-tradable share $X$ net assets per share)/total assets before listing.

\subsubsection{Explanatory Variable}

This paper is based on the actual environment of financing in the listed companies on China GEM. Eight indicators have been selected, which are profitability, earnings quality, capital structure, growth ability, debt paying ability, operation capacity, shareholder structure and technological innovative ability, as well as 25 variables to generally reflect the whole situation of business performance and innovative performance indicators that influence the financing capability of a company before it is listed. Specifics are shown as follows:

Table 1. Descriptive Statistics of Influential Indicators of Financing Capability

\begin{tabular}{|c|c|c|c|c|c|c|}
\hline $\begin{array}{l}\text { Influential } \\
\text { Aspect }\end{array}$ & Variable & $\begin{array}{l}\text { Explanation of } \\
\text { Variable }\end{array}$ & Min. & Max. & Mean & $\begin{array}{l}\text { Standard } \\
\text { Deviatio } \\
\mathrm{n}\end{array}$ \\
\hline $\begin{array}{l}\text { Financing } \\
\text { Capability }\end{array}$ & Y1 & Tobin's Q & 1.91 & 68.04 & 11.4 & 8.51 \\
\hline \multirow{3}{*}{ Profitability } & $\mathrm{X} 1$ & $\begin{array}{l}\text { Net profit ratio } \\
\text { of total assets }\end{array}$ & 0.05 & 0.67 & 0.19 & 0.1 \\
\hline & $\mathrm{X} 2$ & $\begin{array}{l}\text { Return on total } \\
\text { assets }\end{array}$ & 0.07 & 0.73 & 0.23 & 0.1 \\
\hline & $\mathrm{X} 3$ & $\begin{array}{l}\text { Net } \\
\text { profit/gross } \\
\text { revenue }\end{array}$ & 0.03 & 0.58 & 0.2 & 0.1 \\
\hline \multirow[t]{2}{*}{$\begin{array}{l}\text { Earnings } \\
\text { Quality }\end{array}$} & $\mathrm{X} 4$ & $\begin{array}{l}\text { Net earnings } \\
\text { of business } \\
\text { activities/total } \\
\text { profit }\end{array}$ & 0.35 & 1.11 & 0.91 & 0.1 \\
\hline & $\mathrm{X} 5$ & Net operating & -0.14 & 0.62 & 0.16 & 0.13 \\
\hline
\end{tabular}




\begin{tabular}{|c|c|c|c|c|c|c|}
\hline & & $\begin{array}{l}\text { cash } \\
\text { flow/gross } \\
\text { revenue }\end{array}$ & & & & \\
\hline \multirow[t]{2}{*}{$\begin{array}{l}\text { Asset } \\
\text { Structure }\end{array}$} & $\mathrm{X} 6$ & $\begin{array}{l}\text { Current } \\
\text { assets/total } \\
\text { assets }\end{array}$ & 0.11 & 0.99 & 0.71 & 0.16 \\
\hline & $\mathrm{X} 7$ & Total assets & 37901281 & $2.34 \mathrm{E}+09$ & 287553068 & $2.37 \mathrm{E}+08$ \\
\hline \multirow{5}{*}{$\begin{array}{l}\text { Debt Paying } \\
\text { Ability }\end{array}$} & $\mathrm{X} 8$ & $\begin{array}{l}\text { Debt Asset } \\
\text { ratio }\end{array}$ & 0.04 & 0.76 & 0.43 & 0.15 \\
\hline & $\mathrm{X} 9$ & Liquidity ratio & 0.38 & 27.83 & 2.53 & 2.26 \\
\hline & $\mathrm{X} 10$ & Quick ratio & 0.32 & 27.75 & 2.08 & 2.25 \\
\hline & $\mathrm{X} 11$ & $\begin{array}{l}\text { Tangible } \\
\text { assets/total } \\
\text { liability }\end{array}$ & 0.19 & 23.06 & 1.7 & 2.02 \\
\hline & $\mathrm{X} 12$ & $\begin{array}{l}\text { Cash flow } \\
\text { coverage ratio }\end{array}$ & -0.13 & 4.06 & 0.54 & 0.68 \\
\hline \multirow{4}{*}{$\begin{array}{l}\text { Operation } \\
\text { Capacity }\end{array}$} & $\mathrm{X} 13$ & $\begin{array}{l}\text { Rate of stock } \\
\text { turnover }\end{array}$ & 0 & 973377.83 & 2999.7 & 52885.37 \\
\hline & $\mathrm{X} 14$ & $\begin{array}{l}\text { Turnover ratio } \\
\text { of account } \\
\text { payable }\end{array}$ & 0 & 1087.59 & 16.64 & 81.6 \\
\hline & $\mathrm{X} 15$ & $\begin{array}{l}\text { Total assets } \\
\text { turnover }\end{array}$ & 0.17 & 3.68 & 1.05 & 0.42 \\
\hline & $\mathrm{X} 16$ & $\begin{array}{l}\text { Turnover of } \\
\text { account } \\
\text { receivable }\end{array}$ & 0.86 & 281.6 & 10.79 & 25.22 \\
\hline \multirow{3}{*}{$\begin{array}{l}\text { Growth } \\
\text { Ability }\end{array}$} & $\mathrm{X} 17$ & $\begin{array}{l}\text { Growth rate of } \\
\text { gross revenue }\end{array}$ & -0.04 & 5.01 & 0.48 & 0.51 \\
\hline & $\mathrm{X} 18$ & $\begin{array}{l}\text { Growth rate of } \\
\text { net asset }\end{array}$ & -0.01 & 4.73 & 0.75 & 0.74 \\
\hline & X19 & $\begin{array}{l}\text { Growth rate of } \\
\text { total asset }\end{array}$ & -0.02 & 4.42 & 0.53 & 0.53 \\
\hline \multirow{2}{*}{$\begin{array}{l}\text { Nature of } \\
\text { Shareholders }\end{array}$} & $\mathrm{X} 20$ & $\begin{array}{l}\text { Nature of } \\
\text { shareholders }\end{array}$ & 0 & 1 & 0.97 & 0.18 \\
\hline & $\mathrm{X} 21$ & $\begin{array}{l}\text { Age of } \\
\text { enterprise }\end{array}$ & 1.1 & 24 & 10.22 & 3.9 \\
\hline \multirow{4}{*}{$\begin{array}{l}\text { Technological } \\
\text { Innovative } \\
\text { Ability }\end{array}$} & $\mathrm{X} 22$ & $\begin{array}{l}\text { Average } \\
\text { annual } \\
\text { technological } \\
\text { R\&D } \\
\text { expenditure }\end{array}$ & 698675 & 73728713 & 13736963 & 10059109 \\
\hline & $\mathrm{X} 23$ & $\begin{array}{l}\text { Average } \\
\text { annual patent } \\
\text { applications }\end{array}$ & 0 & 274 & 6.98 & 18.5 \\
\hline & $\mathrm{X} 24$ & $\begin{array}{l}\text { Growth rate of } \\
\text { technological } \\
\text { R\&D } \\
\text { expenditure }\end{array}$ & -0.18 & 23.15 & 0.82 & 1.66 \\
\hline & $\mathrm{X} 25$ & $\begin{array}{l}\text { Technological } \\
\text { R\&D } \\
\text { expenditure/to } \\
\text { tal average } \\
\text { operating } \\
\text { costs }\end{array}$ & 0 & 0.62 & 0.08 & 0.07 \\
\hline
\end{tabular}




\subsection{Study Period}

We defined the IPO year as $\mathrm{T}$ year. Then, we calculated the index changes in business and innovative performance 2 years before IPO (T-2), a year before IPO $(\mathrm{T}-1)$, IPO year $(\mathrm{T})$, a year after IPO $(\mathrm{T}+1)$ and 2 years after IPO $(\mathrm{T}+2)$. The financing capability was analyzed with the changes before and after IPO.

\section{Methodology}

The IPO may be related to 25 variables described in section 3.2.2. Due to test the changes in performance before and after IPO, we analyzed which variables have correlation with IPO firstly. Then regression test was used to verify whether there are positive correlation between the correlated explanatory variables selected in first step and explained variables (section 3.2.1). Moreover, entirely analyze the performance changes before and after IPO by descriptive statistics. Finally, performance and innovative ability of GEM companies before and after IPO have been analyzed by Wilcoxon signed-rank test in the aspects of profitability, earnings quality, growth ability, debt paying ability, and technological innovative ability.

\subsection{Correlation Analysis}

SPSS was used for correlation analysis. 340 samples were respectively imported in vector files then the $\mathrm{Y}$ values (total market value of company after IPO/total asset before IPO) that represent financing capability were entered. Meanwhile, respective variables X1-X25 before listing were imported to the table. SPSS analyzed the data and the relative coefficient between explained variables and explanatory variables were obtained, and then carry out the correlation analysis.

\subsection{Regression Test}

In order to check hypothesis 1, Logit regression model was established with Tobin's Q and performance indicators that have relatively high correlation coefficients obtained after the correlation analysis. The model analyzed the influential relationship between all performance indicators with financing capability.

$$
E\left(Y_{1}\right)=a_{0}+a_{t} \sum X_{i}
$$

$\mathrm{Y} 1$ is the Tobin's $\mathrm{Q}$ value and $\mathrm{X}$ is the performance indicator that has relatively high correlation coefficient of affecting financing capability, which is obtained after the correlation analysis.

\subsection{Wilcoxon Signed-Rank Test}

In order for us to test hypothesis 2, main performance indicators that affect financing capability were separated into two groups. Since it was not sure whether the selected samples came from an overall or a normal distribution, Wilcoxon signed-rank test was used to pair these samples in order to test for significant difference. This test accords to the following formula to calculate $\mathrm{Z}$ statistics. Under the condition of large sample size, it is close to obeying gradual normal distribution,

$$
\begin{aligned}
& z=\frac{W-\mu}{\sigma} \sim N(0,1) \\
& W=\min \left(W^{+}, W^{-}\right), \quad \mu=\frac{n(n+1)}{4}, \quad \sigma=\sqrt{\frac{n(n+1)(2 n+1)}{24}}
\end{aligned}
$$

in which $\mu$ is average rank sum, $\sigma^{2}$ is rank sum variance, $W^{+}$is positive rank sum, $W^{-}$is negative rank sum and $n$ is sample size. 


\section{Result}

\subsection{Correlation Analysis of Factors Affecting Financing Capability}

We entered variables Y (total market price after IPO/total asset) with 25 independent variables X1 to X25 into SPSS for all 340 samples then analyzed. The following shows the relative coefficient table.

Table 2. Relative Coefficient of Factors That Affect IPO Financing Capability

\begin{tabular}{|c|c|c|c|}
\hline Influential Aspect & Variable & Explanation of Variable & Y1 \\
\hline \multirow{3}{*}{ Profitability } & $\mathrm{X} 1$ & Net profit ratio of total assets & $0.63^{* \star *}$ \\
\hline & $\mathrm{X} 2$ & Return on total assets & $0.62^{* \star *}$ \\
\hline & $\mathrm{X} 3$ & Net profit/gross revenue & $0.41^{* * *}$ \\
\hline \multirow[t]{2}{*}{ Earnings Quality } & $\mathrm{X} 4$ & $\begin{array}{l}\text { Net earnings of business activities/total } \\
\text { profit }\end{array}$ & -0.01 \\
\hline & $\mathrm{X} 5$ & Net operating cash flow/gross revenue & $0.31^{* * *}$ \\
\hline \multirow{2}{*}{ Asset Structure } & $\mathrm{X6}$ & Current assets/total assets & $0.21^{* * *}$ \\
\hline & $\mathrm{X} 7$ & Total assets & $0.32^{* \star *}$ \\
\hline \multirow{5}{*}{ Debt Paying Ability } & $\mathrm{X} 8$ & Debt Asset ratio & $-0.28^{* * *}$ \\
\hline & $\mathrm{X} 9$ & Current ratio & $0.15^{\star * *}$ \\
\hline & $\mathrm{X} 10$ & Acid-test Ratio & $0.16^{\star * *}$ \\
\hline & $\mathrm{X} 11$ & Tangible assets/total liability & $0.10^{* *}$ \\
\hline & $\mathrm{X} 12$ & Cash flow coverage ratio & $0.36^{* * *}$ \\
\hline \multirow{4}{*}{ Operation Capacity } & $\mathrm{X} 13$ & Rate of stock turnover & -0.04 \\
\hline & $\mathrm{X} 14$ & Turnover ratio of account payable & -0.01 \\
\hline & $\mathrm{X} 15$ & Total assets turnover & $0.19^{* * *}$ \\
\hline & $\mathrm{X} 16$ & Turnover of account receivable & 0.05 \\
\hline \multirow{3}{*}{ Growth Ability } & $\mathrm{X} 17$ & Growth rate of gross revenue & $0.32^{* * *}$ \\
\hline & $\mathrm{X} 18$ & Growth rate of net asset & $0.24^{* \star *}$ \\
\hline & $\mathrm{X} 19$ & Total Assets Growth Rate & $0.28^{* * *}$ \\
\hline \multirow{2}{*}{$\begin{array}{l}\text { Nature of } \\
\text { Shareholders }\end{array}$} & $\mathrm{X} 20$ & Nature of shareholders & -0.03 \\
\hline & $\mathrm{X} 21$ & Age of enterprise & $0.02^{*}$ \\
\hline \multirow{4}{*}{$\begin{array}{l}\text { Technological } \\
\text { Innovative Ability }\end{array}$} & $\mathrm{X} 22$ & $\begin{array}{l}\text { Average annual technological R\&D } \\
\text { expenditure }\end{array}$ & 0.1 \\
\hline & $\mathrm{X} 23$ & Average annual patent applications & -0.01 \\
\hline & $\mathrm{X} 24$ & $\begin{array}{l}\text { Growth rate of technological R\&D } \\
\text { expenditure }\end{array}$ & 0.05 \\
\hline & $\mathrm{X} 25$ & $\begin{array}{l}\text { Technological R\&D expenditure/total } \\
\text { average operating costs }\end{array}$ & $0.30^{* * *}$ \\
\hline
\end{tabular}

Note: $*, * *, * * *$, indicate $\mathrm{Y} 1$ at $10 \%, 5 \%, 1 \%$ significant levels respectively

Through correlation analysis, X1 (net profit ratio of total asset) and X2 (return on total assets), which represent profitability, are closely related. Its relative coefficient is more than 0.6. Financing capability is significantly related to X3 (profit/gross revenue). Moreover, the relative coefficients of financing capability with X5 (net operating cash flow/gross revenue), X12 (cash flow coverage ration), X17 (growth rate of gross revenue) and X25 (technological R\&D expenditure/total average operating costs) are all over 0.3, which indicates a certain correlativity.

From the researching finding, relative coefficient of financing capacity and profitability is the highest and it is relatively significant. Moreover, generally in IPO enterprise, 
investors pay more attention to a company's profit index. This is consistent with our analysis results. Secondly, we found that "earnings quality", growth ability and debt paying ability of a company are also closely related to financing capacity. Through our correlative analysis, it is found that in the four indicators that represent innovation investment, $R \& D$ strength $(R \& D$ investment/operating cost) and financing capacity are significantly related. The rest of technological innovative indicators do not have correlation with financing capacity. In actual IPO companies, investors normally have difficulty in obtaining data and other relevant information on technological innovation, except professional investment organizations. Within a professional investment organization, everyone may pay more attention to the profitability, growth ability and earnings quality of a company while less focus on debt paying ability and operating capacity.

\subsection{Regression Results}

We performed regression analysis on influencing factors selected from correlation analysis to further check whether these variables have linear relation with Y. They are shown as follows:

Table 3. Regression Analysis of Variables that Affect Financing

\begin{tabular}{l|r|r|r|r}
\hline & Coefficient & $\begin{array}{c}\text { Standard } \\
\text { Error }\end{array}$ & \multicolumn{1}{c|}{ t-statistic } & \multicolumn{1}{c}{ Sig. } \\
\hline Constant & 0.545 & 1.11 & 0.491 & 0.624 \\
\hline X1: Net profit ratio of total assets & 95.487 & 26.378 & 3.62 & 0 \\
\hline X2: Return on total assets & -33.449 & 23.677 & -1.413 & 0.159 \\
\hline X3: Net profit/gross revenue & -11.129 & 6.926 & -1.607 & 0.109 \\
\hline $\begin{array}{l}\text { X5: Net operating cash flow/gross } \\
\text { revenue }\end{array}$ & 5.722 & 4.59 & 1.247 & 0.031 \\
\hline X12: Cash flow coverage ratio & -1.377 & 0.867 & -1.589 & 0.113 \\
\hline X17: Growth rate of gross revenue & 2.871 & 0.72 & 3.985 & 0 \\
\hline X35: R\&D strength & 8.453 & 7.193 & 1.175 & 0.071 \\
\hline
\end{tabular}

Note $: \mathrm{R}^{2}=0.44, \mathrm{~N}=339$

Through the results of regression analysis, we can see that in the factors that affect financing capability, net profit ratio of total asset is positively correlated to financing capability at a remarkable level of $1 \%$. As the net profit ratio of total asset increases $1 \%$, financing capability rises to $95 \%$. "Net operating cash flow/gross revenue", which represents earnings quality, also has a positive correlation with financing capacity. As "net operating cash flow/gross revenue" increases 1\%, Tobin's Q increases 5.77 and is shown significantly at 5\%. Similarly, growth rate of gross revenue, which represents growth ability, is a relatively large influential factor on financing capability with a positive correlation at $1 \%$ level. As revenue increases $1 \%$, financing capacity raises $2.87 \%$. In addition, R\&D strength, representing technological innovative ability, also has a positive correlation with financing capability. As it grows 1\%, Tobin's Q increases 8.45 and is shown at a $10 \%$ level. We can verify hypothesis 1 by above analysis. That is the financing capability has clear positive correlation with company performance, in which profitability, earnings quality, growth ability and R\&D strength have significant correlation with company's IPO financing capability.

\subsection{Descriptive Statistics and Comparative Analysis}

We used 4.1 to find out the 7 most important factors that affect company IPO financing capability as indictors that tested changes in performance before and after IPO. We used T 
as the IPO of that year. Then, we calculated the index changes in business and innovative performance as well as amount of variation 2 years before IPO (T-2), a year before IPO $(\mathrm{T}-1)$, IPO year $(\mathrm{T})$, a year after IPO $(\mathrm{T}+1)$ and 2 years after IPO $(\mathrm{T}+2)$.

Table 4. Data Comparison of Performance Indicators before and after IPO

\begin{tabular}{l|l|c|c|c|c|c}
\hline \multicolumn{1}{c|}{$\begin{array}{c}\text { Evaluation } \\
\text { Aspects }\end{array}$} & \multicolumn{1}{|c|}{ Name of Indicator } & $\mathrm{T}-2$ & $\mathrm{~T}-1$ & $\mathrm{~T}$ & $\mathrm{~T}+1$ & $\mathrm{~T}+2$ \\
\hline \multirow{3}{*}{ Profit-ability } & $\begin{array}{l}\text { Net profit ratio of } \\
\text { total assets }\end{array}$ & 0.207 & 0.206 & 0.099 & 0.064 & 0.054 \\
\cline { 2 - 7 } & Return on total assets & 0.245 & 0.244 & 0.11 & 0.066 & 0.059 \\
\cline { 2 - 7 } & $\begin{array}{l}\text { Net profit/gross } \\
\text { revenue }\end{array}$ & 0.205 & 0.215 & 0.206 & 0.171 & 0.128 \\
\hline $\begin{array}{l}\text { Earnings } \\
\text { Quality }\end{array}$ & $\begin{array}{l}\text { Net operating cash } \\
\text { flow/gross revenue }\end{array}$ & 0.169 & 0.172 & 0.064 & 0.063 & 0.068 \\
\hline $\begin{array}{l}\text { Debt Paying } \\
\text { Ability }\end{array}$ & $\begin{array}{l}\text { Cash flow coverage } \\
\text { ratio }\end{array}$ & 0.553 & 0.663 & 0.431 & 0.322 & 0.317 \\
\hline Growth Ability & $\begin{array}{l}\text { Growth rate of gross } \\
\text { revenue }\end{array}$ & 0.575 & 0.387 & 0.248 & 0.227 & 0.239 \\
\hline $\begin{array}{l}\text { Technological } \\
\text { Innovative } \\
\text { Ability }\end{array}$ & $\begin{array}{l}\text { Average annual } \\
\text { patent applications }\end{array}$ & 9.858 & 13.825 & 14.643 & 17.499 & 18.396 \\
\cline { 2 - 7 } & R\&D strength & 0.081 & 0.079 & 0.086 & 0.103 & 0.099 \\
\hline
\end{tabular}

Table 5. Descriptive Statistics of Performance Indicators before and after IPO

\begin{tabular}{|c|c|c|c|c|c|c|c|c|}
\hline & \multicolumn{4}{|c|}{ Before IPO } & \multicolumn{4}{|c|}{ After IPO } \\
\hline $\begin{array}{l}\text { Evaluation } \\
\text { Index }\end{array}$ & Mean & $\begin{array}{l}\text { Standard } \\
\text { Dev. }\end{array}$ & Min. & Max. & Mean & $\begin{array}{l}\text { Standard } \\
\text { Dev. }\end{array}$ & Min. & Max. \\
\hline $\begin{array}{l}\text { Net profit } \\
\text { ratio of } \\
\text { total assets }\end{array}$ & 0.195 & 0.097 & 0.048 & 0.669 & 0.067 & 0.036 & -0.067 & 0.205 \\
\hline $\begin{array}{l}\text { Return on } \\
\text { total assets }\end{array}$ & 0.231 & 0.105 & 0.067 & 0.726 & 0.074 & 0.039 & -0.06 & 0.221 \\
\hline $\begin{array}{l}\text { Net } \\
\text { profit/gross } \\
\text { revenue }\end{array}$ & 0.203 & 0.102 & 0.03 & 0.577 & 0.15 & 0.11 & -0.562 & 0.516 \\
\hline $\begin{array}{l}\text { Net } \\
\text { operating } \\
\text { cash } \\
\text { flow/gross } \\
\text { revenue }\end{array}$ & 0.162 & 0.128 & -0.136 & 0.625 & 0.073 & 0.156 & -0.451 & 1.36 \\
\hline $\begin{array}{l}\text { Cash flow } \\
\text { coverage } \\
\text { ratio }\end{array}$ & 0.544 & 0.676 & -0.133 & 4.065 & 0.342 & 0.653 & -0.553 & 5.622 \\
\hline $\begin{array}{l}\text { Growth rate } \\
\text { of gross } \\
\text { revenue }\end{array}$ & 0.481 & 0.509 & -0.042 & 5.013 & 0.248 & 0.215 & -0.346 & 1.849 \\
\hline $\begin{array}{l}\text { Average } \\
\text { annual } \\
\text { patent } \\
\text { applications }\end{array}$ & 6.985 & 18.501 & 0 & 274 & 16.551 & 29.139 & 0 & 397.5 \\
\hline
\end{tabular}




\begin{tabular}{l|l|l|l|l|l|l|l|l}
\hline $\begin{array}{l}\text { R\&D } \\
\text { strength }\end{array}$ & 0.082 & 0.07 & 0.003 & 0.62 & 0.096 & 0.091 & 0.009 & 0.628 \\
\hline
\end{tabular}

\subsection{Wilcoxon Signed-Rank Results}

\subsubsection{Profitability}

Net profit ratio of total assets and return on total assets are negative values in all comparative groups during window period and the results in comparing one and two years before listing are not significant, but they are more significant compared to other groups. Therefore, this indicates the net profit ratio of total assets and return on total assets of GEM companies are basically getting worst year by year during our chosen window period before and after IPO.

In comparison of two window period groups (T-1) with (T-2) and (T) with (T-2) of net profit/gross revenue mean value, the change of mean values are positive with significant test results. This shows that the net profit/gross revenue of GEM listing companies overall increased one and two years before listing, but other tested groups have negative mean values. Therefore, we can believe that in the window period, the net profit/gross revenue of GEM listing companies appear to gradually worsen starting from one year before listing

Table 6. Wilcoxon Signed-Rank Test on Profitability

\begin{tabular}{|c|c|c|c|c|c|c|c|c|c|}
\hline \multirow[b]{2}{*}{$\begin{array}{l}\text { Test } \\
\text { Period }\end{array}$} & \multicolumn{3}{|c|}{$\begin{array}{c}\text { Net profit ratio of total } \\
\text { assets }\end{array}$} & \multicolumn{3}{|c|}{ Return on total assets } & \multicolumn{3}{|c|}{ Net profit/gross revenue } \\
\hline & Mean & Z Value & $\begin{array}{c}\text { Asymptotic } \\
\text { Significance } \\
\text { (bilateral) }\end{array}$ & Mean & $\begin{array}{l}\mathbf{Z} \\
\text { Value }\end{array}$ & $\begin{array}{c}\text { Asymptotic } \\
\text { Significance } \\
\text { (bilateral) }\end{array}$ & Mean & Z & $\begin{array}{c}\text { Asymptotic } \\
\text { Significance } \\
\text { (bilateral) }\end{array}$ \\
\hline $\begin{array}{l}(\mathrm{T}-1)- \\
(\mathrm{T}-2)\end{array}$ & 0 & 0.83 & 0.41 & 0 & 0.82 & 0.41 & 0.01 & 5.96 & 0.00 \\
\hline $\begin{array}{c}\mathrm{T}- \\
(\mathrm{T}-2)\end{array}$ & -0.11 & -15.58 & 0.00 & -0.13 & -15.79 & 0.00 & 0 & 0.69 & 0.49 \\
\hline $\begin{array}{l}(\mathrm{T}+1)- \\
(\mathrm{T}-2)\end{array}$ & -0.14 & -15.87 & 0.00 & -0.18 & -15.93 & 0.00 & -0.03 & -7.16 & 0.00 \\
\hline $\begin{array}{l}(\mathrm{T}+2)- \\
(\mathrm{T}-2)\end{array}$ & -0.15 & -15.69 & 0.00 & -0.19 & -15.77 & 0.00 & -0.08 & -11.52 & 0.00 \\
\hline $\begin{array}{c}\mathrm{T}- \\
(\mathrm{T}-1)\end{array}$ & -0.11 & -15.89 & 0.00 & -0.13 & -15.92 & 0.00 & -0.01 & -4.71 & 0.00 \\
\hline $\begin{array}{l}(\mathrm{T}+1)- \\
(\mathrm{T}-1)\end{array}$ & -0.14 & -15.93 & 0.00 & -0.18 & -15.95 & 0.00 & -0.04 & -10.14 & 0.00 \\
\hline $\begin{array}{l}(\mathrm{T}+2)- \\
(\mathrm{T}-1)\end{array}$ & -0.15 & -15.74 & 0.00 & -0.19 & -15.78 & 0.00 & -0.09 & -13.44 & 0.00 \\
\hline $\begin{array}{c}(T+1)- \\
T\end{array}$ & -0.04 & -15.26 & 0.00 & -0.04 & -15.36 & 0.00 & -0.03 & -10.8 & 0.00 \\
\hline $\begin{array}{c}(T+2)- \\
T\end{array}$ & -0.05 & -14.58 & 0.00 & -0.05 & -14.39 & 0.00 & -0.08 & -13.87 & 0.00 \\
\hline $\begin{array}{l}(T+2)- \\
(T+1)\end{array}$ & -0.01 & -5.77 & 0.00 & -0.01 & -3.46 & 0.00 & -0.04 & -11 & 0.00 \\
\hline
\end{tabular}

\subsubsection{Earnings Quality}

From the table, it is shown that although the net operating cash flow/gross revenue in comparing groups of (T-1) with (T-2), (T+2) with $(\mathrm{T})$ and $(\mathrm{T}+2)$ with $(\mathrm{T}+1)$ has positive mean values but not significant, but mean values in the other 7 comparing groups are negative. Except the (T-1)-(T-2) group, the test results of the other 6 groups are clearly on the $1 \%$ confidence level. Therefore, it can be believed that in the window period, the net operating cash flow/gross revenue of GEM listing companies appear to gradually worsen year by year. 
Table 7. Wilcoxon Signed-Rank Test on Earnings Quality

\begin{tabular}{c|l|c|c|c}
\hline \multirow{3}{*}{ Financial indicator } & \multirow{2}{*}{ Test period } & \multicolumn{3}{|c}{ Wilcoxon signed-rank test } \\
\cline { 3 - 5 } & & Mean & $\begin{array}{c}\text { Z } \\
\text { Value }\end{array}$ & $\begin{array}{c}\text { Asymptotic significance } \\
\text { (bilateral) }\end{array}$ \\
\hline \multirow{5}{*}{$\begin{array}{c}\text { Net operating cash } \\
\text { flow/gross revenue }\end{array}$} & $(\mathrm{T}-1)-(\mathrm{T}-2)$ & 0.00 & -0.34 & 0.73 \\
\cline { 2 - 5 } & $\mathrm{T}-(\mathrm{T}-2)$ & -0.11 & -9.69 & 0.00 \\
\cline { 2 - 5 } & $(\mathrm{T}+1)-(\mathrm{T}-2)$ & -0.11 & -9.67 & 0.00 \\
\cline { 2 - 5 } & $(\mathrm{T}+2)-(\mathrm{T}-2)$ & -0.10 & -9.08 & 0.00 \\
\cline { 2 - 5 } & $\mathrm{T}-(\mathrm{T}-1)$ & -0.11 & -10.63 & 0.00 \\
\cline { 2 - 5 } & $(\mathrm{T}+1)-(\mathrm{T}-1)$ & -0.11 & -10.02 & 0.00 \\
\cline { 2 - 5 } & $(\mathrm{T}+2)-(\mathrm{T}-1)$ & -0.10 & -9.97 & 0.00 \\
\cline { 2 - 5 } & $(\mathrm{T}+1)-\mathrm{T}$ & 0.00 & 0.27 & 0.79 \\
\cline { 2 - 5 } & $(\mathrm{I}+2)-\mathrm{T}$ & 0.00 & 0.37 & 0.71 \\
\cline { 2 - 5 } & $(\mathrm{T}+2)-(\mathrm{T}+1)$ & 0.00 & 0.31 & 0.76 \\
\hline
\end{tabular}

\subsubsection{Debt Paying Ability}

From Table 8, it can be shown that the cash flow coverage ratio (net cash flow/current liabilities) only has positive mean value in the (I-1) with (I-2) comparison group and it is significant under $5 \%$ of confidence level. The other 9 groups have negative mean values. In these 9 groups, test results for 3 groups, which are $(\mathrm{T}+1)$ with $(\mathrm{T}), \quad(\mathrm{T}+2)$ with $(\mathrm{T})$ and $(\mathrm{I}+2)$ with $(\mathrm{I}+1)$ are not significant. The test results for the rest are notable on $1 \%$ level. This means the cash flow coverage ratio produced by GEM listed company's business activities during the window period is gradually worsened year by year.

Table 8. Wilcoxon Signed-Rank Test on Debt Paying Ability

\begin{tabular}{c|l|c|c|c}
\hline \multirow{3}{*}{ Financial indicator } & \multirow{2}{*}{ Test period } & \multicolumn{3}{|c}{ Wilcoxon signed-rank test } \\
\cline { 3 - 5 } & & Mean & $\begin{array}{c}\text { Z } \\
\text { Value }\end{array}$ & $\begin{array}{c}\text { Asymptotic significance } \\
\text { (bilateral) }\end{array}$ \\
\hline \multirow{5}{*}{$\begin{array}{c}\text { Cash } \\
\text { flow coverage ratio }\end{array}$} & $(\mathrm{T}-1)-(\mathrm{T}-2)$ & 0.11 & 2.18 & 0.03 \\
\cline { 2 - 5 } & $\mathrm{T}-(\mathrm{T}-2)$ & -0.12 & -4.57 & 0.00 \\
\cline { 2 - 5 } & $(\mathrm{T}+1)-(\mathrm{T}-2)$ & -0.23 & -6.26 & 0.00 \\
\cline { 2 - 5 } & $(\mathrm{T}+2)-(\mathrm{T}-2)$ & -0.24 & -6.92 & 0.00 \\
\cline { 2 - 5 } & $\mathrm{T}-(\mathrm{T}-1)$ & -0.23 & -7.08 & 0.00 \\
\cline { 2 - 5 } & $(\mathrm{T}+1)-(\mathrm{T}-1)$ & -0.34 & -8.23 & 0.00 \\
\cline { 2 - 5 } & $(\mathrm{T}+2)-(\mathrm{T}-1)$ & -0.35 & -9.14 & 0.00 \\
\cline { 2 - 5 } & $(\mathrm{T}+1)-\mathrm{T}$ & -0.11 & -1.53 & 0.13 \\
\cline { 2 - 5 } & $(\mathrm{I}+2)-\mathrm{T}$ & -0.11 & -1.53 & 0.13 \\
\cline { 2 - 5 } & $(\mathrm{T}+2)-(\mathrm{T}+1)$ & 0.00 & -0.35 & 0.73 \\
\hline
\end{tabular}

\subsubsection{Growth Ability}

The table indicates that the growth rate of gross revenue only has one comparing group, which is $(\mathrm{T}+2)$ with $(\mathrm{T}+1)$, that has a positive mean value. Groups $(\mathrm{T}+1)$ with $\mathrm{T}$ and $(\mathrm{T}+2)$ with $\mathrm{T}$ are also the same, not very notable. For the rest of the comparing groups, the mean values are negative and all of them are clearly on the $1 \%$ confidence level. Therefore, the growth rate of gross revenue of a GEM listed company during the window period is overall gradually worsened year by year. 
Table 9. Wilcoxon Signed-Rank Test on Growth Ability

\begin{tabular}{c|l|c|c|c}
\hline \multirow{3}{*}{ Financial indicator } & \multirow{2}{*}{ Test period } & \multicolumn{3}{|c}{ Wilcoxon signed-rank test } \\
\cline { 3 - 5 } & & Mean & $\begin{array}{c}\text { Z } \\
\text { Value }\end{array}$ & $\begin{array}{c}\text { Asymptotic significance } \\
\text { (bilateral) }\end{array}$ \\
\hline \multirow{4}{*}{$\begin{array}{c}\text { Growth rate of gross } \\
\text { revenue }\end{array}$} & $(\mathrm{T}-1)-(\mathrm{T}-2)$ & -0.19 & -3.26 & 0.00 \\
\cline { 2 - 5 } & $\mathrm{T}-(\mathrm{T}-2)$ & -0.33 & -8.40 & 0.00 \\
\cline { 2 - 5 } & $(\mathrm{T}+1)-(\mathrm{T}-2)$ & -0.35 & -8.82 & 0.00 \\
\cline { 2 - 5 } & $(\mathrm{T}+2)-(\mathrm{T}-2)$ & -0.34 & -8.33 & 0.00 \\
\cline { 2 - 5 } & $\mathrm{T}-(\mathrm{T}-1)$ & -0.14 & -7.58 & 0.00 \\
\cline { 2 - 5 } & $(\mathrm{T}+1)-(\mathrm{T}-1)$ & -0.16 & -6.69 & 0.00 \\
\cline { 2 - 5 } & $(\mathrm{T}+2)-(\mathrm{T}-1)$ & -0.15 & -6.76 & 0.00 \\
\cline { 2 - 5 } & $(\mathrm{T}+1)-\mathrm{T}$ & -0.02 & -1.26 & 0.21 \\
\cline { 2 - 5 } & $(\mathrm{I}+2)-\mathrm{T}$ & -0.01 & -0.28 & 0.78 \\
\cline { 2 - 5 } & $(\mathrm{T}+2)-(\mathrm{T}+1)$ & 0.01 & 0.39 & 0.70 \\
\hline
\end{tabular}

\subsubsection{Technological Innovative Ability}

Firstly, the mean values in all groups for annual average patent applications are positive. Despite that the test results of group $(T+2)$ with $(T+1)$ is not significant, the $T$ with (T-1) group resulted in a notable 5\% confidence level. Meanwhile, results for other groups are on a significant $1 \%$ confidence level. Secondly for the R\&D strength (technological $\mathrm{R} \& \mathrm{D}$ investment/total operating cost), the mean values for two groups ( $\mathrm{T}$ 1) with $(\mathrm{T}-2)$ and $(\mathrm{T}+2)$ with $(\mathrm{T}+1)$ are negative, but these results are not significant. Mean values for other groups are all positive at a significant $1 \%$ confidence level. Therefore, it is believed that the number of patent application and R\&D strength of a GEM listed company after IPO are overall gradually increasing year by year.

\section{Table 10. Wilcoxon Signed-Rank Test on Technological Innovative Ability}

\begin{tabular}{|c|c|c|c|c|c|c|c|c|c|}
\hline \multirow[b]{2}{*}{$\begin{array}{c}\text { Test } \\
\text { Period }\end{array}$} & \multicolumn{3}{|c|}{ Net profit ratio of total assets } & \multicolumn{3}{|c|}{ Return on total assets } & \multicolumn{3}{|c|}{ Net profit/gross revenue } \\
\hline & Mean & $Z_{\text {Value }}$ & $\begin{array}{c}\text { Asymptotic } \\
\text { Significance } \\
\text { (bilateral) } \\
\end{array}$ & Mean & $\begin{array}{l}\text { Z } \\
\text { Value }\end{array}$ & $\begin{array}{c}\text { Asymptotic } \\
\text { Significance } \\
\text { (bilateral) } \\
\end{array}$ & Mean & \begin{tabular}{|l} 
Z \\
Value
\end{tabular} & $\begin{array}{c}\text { Asymptotic } \\
\text { Significance } \\
\text { (bilateral) } \\
\end{array}$ \\
\hline $\begin{array}{l}(T-1)- \\
(T-2)\end{array}$ & 3.97 & 5.43 & 0.00 & 0 & -0.91 & 0.37 & 3.97 & 5.43 & 0.00 \\
\hline $\begin{array}{c}\text { T- } \\
(\mathrm{T}-2)\end{array}$ & 4.78 & 5.4 & 0.00 & 0 & 2.69 & 0.01 & 4.78 & 5.4 & 0.00 \\
\hline $\begin{array}{c}(\mathrm{T}+1)- \\
(\mathrm{T}-2)\end{array}$ & 7.64 & 7.5 & 0.00 & 0.02 & 5.1 & 0.00 & 7.64 & 7.5 & 0.00 \\
\hline $\begin{array}{c}(\mathrm{T}+2)- \\
(\mathrm{T}-2)\end{array}$ & 8.54 & 7.27 & 0.00 & 0.02 & 3.99 & 0.00 & 8.54 & 7.27 & 0.00 \\
\hline $\begin{array}{c}\text { T- } \\
(\mathrm{T}-1)\end{array}$ & 0.82 & 2.11 & 0.04 & 0.01 & 3.46 & 0.00 & 0.82 & 2.11 & 0.04 \\
\hline $\begin{array}{c}(\mathrm{T}+1)- \\
(\mathrm{T}-1)\end{array}$ & 3.67 & 4.16 & 0.00 & 0.02 & 5.85 & 0.00 & 3.67 & 4.16 & 0.00 \\
\hline $\begin{array}{c}(\mathrm{T}+2)- \\
(\mathrm{T}-1)\end{array}$ & 4.57 & 4.26 & 0.00 & 0.02 & 3.59 & 0.00 & 4.57 & 4.26 & 0.00 \\
\hline $\begin{array}{c}(T+1)- \\
T\end{array}$ & 2.86 & 3.16 & 0.00 & 0.02 & 3.79 & 0.00 & 2.86 & 3.16 & 0.00 \\
\hline $\begin{array}{c}(\mathbf{T}+2)- \\
\mathrm{T}\end{array}$ & 3.75 & 2.82 & 0.00 & 0.01 & 2.18 & 0.03 & 3.75 & 2.82 & 0.00 \\
\hline $\begin{array}{c}(\mathrm{T}+2)- \\
(\mathrm{T}+1)\end{array}$ & 0.9 & 1.38 & 0.17 & 0 & -1.09 & 0.27 & 0.9 & 1.38 & 0.17 \\
\hline
\end{tabular}




\section{Discussion}

In this paper, we confirmed the financing indexes of GEM listed companies' business shows significantly worse result after IPO than before IPO, illustrating that going public hasn't promoted the business performances of the enterprises. At least in a short time, the business performances of the listed enterprises fall, which may reflect that there are resource allocating deficiency, unreasonable usage of fund and even waste of resources of GEM listed companies in financing, suggesting that although CSRC has increasingly strict requirements and inspections on IPO of GEM listed companies, a number of enterprises still boost their book surpluses to meet the listing standards.

However, although there is an obviously decrease on the business performances after IPO, the innovation indexes increase year after year. In the term of technological innovation capacity, the number of annual patent applications by listed companies has increased remarkably during the study period and risen even more significantly after IPO. But overall the R\&D shows an increasing trend, which shows that Chinese GEM listed companies have paid increasing attention on the enhancement of technological innovation capacity and the protection of patent and intellectual property.

\section{Conclusion and Outlook}

This paper statistically analyzed 340 listed companies from 2009 to 2013. The influences that affect IPO financing capability including profitability, earnings quality, debt paying ability, growth ability, technological innovative ability and other aspects are summarized and resulted in the following conclusions:

Financing capability and company performance have significant positive correlation. Moreover in the evaluation system of company performance, profitability, earnings quality, growth ability and R\&D strength have notable correlation with the company's IPO financing capability.

Before IPO, all the business indicators of companies have a certain rise while all the business indicators are found to decline after IPO. The growth ability of business declines. After IPO, the GEM listed companies have poor profitability. Therefore, business performance of the GEM listed companies significantly decline and the operating data of companies before IPO exist "exaggeration" with the phenomenon of IPO effect. The growing prospect for the future is very worrying.

Nevertheless, the investment of the technological innovative ability and the patent application number are shown to increase gradually. Although technological innovation has a relatively positive effect on business performance, this kind of effect is long-term and slow, which cannot reflect the improvement on the business performance in a short period. This is to remind us that we should continually increase the investment ratio for technological innovation as well as enhance the awareness of intellectual property protection and the changes of operation ability due to technological results.

\section{References}

[1] Y. Li and M. Ding, "GEM and Financing of New High-tech Enterprises", Business Economics, vol.1, no.8, (2008), pp.72-73.

[2] Y. Tse and E. Devos. "Trading costs, investor recognition and market response: An analysis of firms that move from the Amex (NASDAQ) to NASDAQ (Amex)", Journal of Banking \& Finance, vol. 1, no.28, (2004), pp.63-83.

[3] B. S. Black and R. J. Gilson. "Venture Capital And the Structure of Capital Markets: Banks Versus Stock Markets", Journal of Financial Economics. vol. 1, no.47, (1998), pp.243-277.

[4] T. Adam, and V.K. Goya L., "The Investment Opportunity Set and Its Proxy Variables", Journal of Financial Research, vol. 1, no.31, (2008), pp.41-63. 
[5] D. Su, "Diverse Operations and Enterprise Value: Empirical Analysis of Chinese Listed Companies", Diversification Premium", Economics (quarterly), vol. 3, no. 4, (2005), pp. 135-136.

[6] Y. Zhang and C. Li, "Ownership Structure, Cash Flow and Capital Investment", Economics (quarterly), vol. 4, no.4, (2005), pp. 229-246.

[7] H. Wang, "Yanfen Meng. Research Based on Capacity of Enterprise Competitiveness", Science Research Management, vol. 6, no.25, (2004), pp.56-59.

[8] X. Zheng and L. Dong. "Financing Capability of State-Owned Enterprises in China-Evolution Path and Influencing Factors", Industrial Technology Economics, vol.25, no.1, (2006), pp.135-139.

[9] L. Zhang and W. Yin. "Analysis of Financing Capability of Listed Electric Companies and Other Influencing Factors", Industrial Technology Economics, vol.25, no.2, (2006), pp.87-89.

[10] M. Lean and R D. Zhao, "The Business Cycle, Investor Sentiment and Costly External Finance", The Journal of Finance and Money, vol.69, no.3, (2014), pp.1399-1409.

[11] W. Lu and H. Zhu, "Research on Changes of IPO Companies' Business Performance and Ownership Structure ", Journal of Finance and Economics, vol.1, no.4, (2001), pp.22-29.

[12] L. Xie and X. Zhu, "Empirical Study on Changes of Performance in Chinese Private Enterprises before and after Listing", Modern Economic Science, vol.1, no.1, (2005), pp.7-9.

[13] G. Zhao, "Research of Issues on Changes of Business Performance in Chinese Private Enterprises 、 before and after IPO", [D]. PhD Thesis of Liaoning University, (2009), pp.78-86.

[14] R.S. Hansen and C. Crutchley, "Corporate financings and earnings: An empirical analysis", Journal of Business, vol.1, no.63, (1990), pp.347-371.

[15] H. W. Lee, "Post Offering Earnings Performance of Firms that Issue Seasoned Equity: The Role of Growth", The Quarterly Review of Economics and Finance, vol.1, no.37, (1997), pp.97-114.

[16] M. Goergen and L. Renneboog, "Why Are the Levels of Control (So) Different in German and U.K. Companies? Evidence from Initial Public Offerings", Journal of Law Economics and Organization, vol.1, no.19, (2003), pp141-175.

\section{Authors}
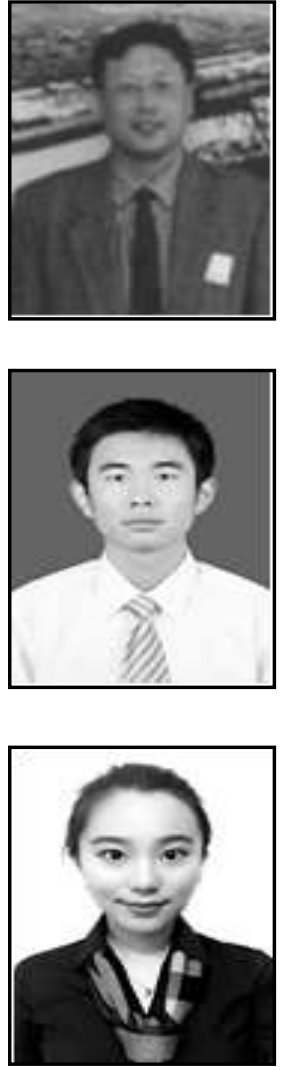

Xiangdong Chen, he is professor in School of Economics and Management at Beihang University, his main teaching and scientific research fields: transnational corporations, foreign direct investment and international technology transfer, technology innovation and knowledge innovation management, international intellectual property protection, patent quality analysis.

Fei Wang, he is phD candidate in School of Economics and Management at Beihang University. As a student, his research includes Corporate Finance, Technology Innovation.

Wei Wang, she is M.Sc. candidate in Faculty of Geoinformation Science and Earth Observation (ITC), University of Twente. Her research interests are mineral and petroleum exploration, data anaysis and application of remote sensing in earth sciences. 